\title{
Effect of Foreign Language Classroom Anxiety on Turkish University Students' Academic Achievement in Foreign Language Learning
}

\author{
Murat Tuncer ${ }^{1}$, Yunus Doğan ${ }^{2}$ \\ ${ }^{1}$ Education Faculty, Firat University, Elazığ, Turkey \\ ${ }^{2}$ School of Foreign Languages, Firat University, Elazığ, Turkey \\ Correspondence: Murat Tuncer, Education Faculty, Firat University, Elazığ, 23119, Turkey
}

Received: August 4, 2015 Accepted: August 6,2015 Online Published: August 17, 2015

doi:10.11114/jets.v3i6.998 URL: http://dx.doi.org/10.11114/jets.v3i6.998

\begin{abstract}
This study was carried out in order to identify to what extent the Turkish students' English classroom anxiety affects their academic achievement in English language. In this quantitative descriptive study, a correlational survey model was employed, and the convenience sampling was done. In order to collect data, the Foreign Language Classroom Anxiety Scale developed by Horwitz, Horwitz and Cope (1986) was used. The latest validity-reliability of this scale was conducted by Gürsu (2011), in which the three-factor structure of the scale was confirmed. The test-retest correlation of the scale was found as .85 . This study was conducted with 271 university engineering students receiving compulsory prep-class education at Firat University during the academic year of 2012-2013. The data of the study were analyzed with the logistic regression analysis. According to the findings, the foreign language anxiety at the beginning of the prep-class education was not effective as the predictor of the academic achievement. On the other hand, it was observed that the students' anxiety, at the end of the education, accounted for the academic failure with its speaking anxiety in language class dimension, and predicted academic achievement with its interest towards language class dimension. This study revealed that the students' anxiety evolving and ever-increasing during their English prep-education powerfully predicted their academic performance. Whatever its source may be, anxiety in learning environments is mostly an unwanted situation. Therefore, it has always been underlined in the literature that in order to facilitate learners' language learning process, the effect of anxiety should be minimized.
\end{abstract}

Keywords: foreign language anxiety, anxiety, achievement, prep-class education

\section{Introduction}

Anxiety has commonly been regarded as one of the most important affective obstacles in language learning achievement, and has been the subject matter of many second/foreign language researches (MacIntyre\&Gregersen, 2012; Huang, 2012; Hewitt\&Stefenson, 2011; Riasati, 2011; Horwitz, 2010; Horwitz, 2001; Young, 1999; Oxford, 1999; Aida, 1994;MacIntyre\&Gardner, 1991; Young, 1991; Horwitz, Horwitz\&Cope, 1986). It was emphasized in some second language theories (Krashen, 1982; Curran et al., 1960) that since anxiety impedes language acquisition, low-anxious learning environments should be created for learners (Huang, 2012).Foreign language anxiety was conceived by Horwitz, Horwitz and Cope (1986) as "a distinct complex of self-perceptions, beliefs, feelings, and behaviors related to classroom language learning arising from the uniqueness of the language learning process". In other words, foreign language anxiety is a term which comprises feelings of worry, and negative and fearful emotions related with an individual's learning or using a language which is not his/ her mother language (MacIntyre \& Gregersen, 2012).

MacIntyre and Gardner (1989) suggest that students do not start language learning with anxiety, but anxiety is a learned emotional reaction, and it appears after students' attitudes towards language learning develop. After a few experiences within the foreign language context, the learner develops attitudes and feelings toward this learning a new language situation. If these experiences are negative, foreign language anxiety may begin to develop; and as these negative experiences continue, foreign language anxiety turn out to be something that happens constantly, and the learner begins to be anxious and perform badly. Poor performance and negative emotional reactions intensify anxiety and failure expectations; and subsequent anxiety is a reaction against this perceived threat (MacIntyre and Gardner, 1991). It has been reported that foreign language classes are the most anxiety-provoking classes (Horwitz et al., 1986; MacIntyre \& Gardner, 1991; Campbell \& Ortiz, 1991; Onwuegbuzie et al., 1999). It can be understood from the relevant studies that 
the relationship between anxiety and academic achievement exhibits often a mutual structure. As the learner's academic performance worsens, his/her level of anxiety related to certain academic tasks increases (Huberty, 2009). In the same vein, it is well-known that an anxious learner will be academically unsuccessful. On the other hand, MacIntyre (1995) claims that anxiety may be the cause, rather than the result, of poor performance; whereas Horwitz (2001) states that to determine to what extent this is so is the real difficulty.

In many studies conducted both at home and abroad, it was found out that there is a negative correlation between foreign language anxiety and success in language learning or language proficiency, and foreign language anxiety negatively affects the academic achievement in language learning (Proulx, 1991; Aida, 1994; Horwitz, 2001; Demirdaş \& Bozdoğan, 2013; Demirdaş, 2012; Köroğlu, 2010; Kılıç, 2007; Batumlu, 2006; Gülsün, 1997; Kunt, 1997; Trylong, 1987; Saito et al., 1999; Phillips, 1992; Ganschow et al., 1994; Sparks et al., 2000; von Wörde, 2003; Chan \& Wu, 2004; Hao et al., 2004; Elkhafaifi, 2005; Awan et al., 2010; Wang, 2011). The meta-analyses findings consistently show significant negative relations typically ranging from -.20 to -.25 between anxiety and achievement outcomes (Goetz and Hall, 2013).When the relevant studies are examined, the importance of further investigating the relation between foreign language anxiety and academic achievement in foreign language learning is well established in terms of Turkish students. In this regard, this study was carried out to identify to what extent the Turkish students' English classroom anxiety affects their academic achievement in English language. To this end, the study aimed to investigate the following two research questions:

1. What is the effect of foreign language classroom anxiety, if any, on the students' achievement scores of the English proficiency test done before the compulsory prep-class education?

2. What is the effect of foreign language classroom anxiety, if any, on the students' achievement scores of the English proficiency test done at the end of the compulsory prep-class education?

\section{Method}

This descriptive quantitative study was carried out in the correlational survey model. The population of the study involved the university students at Firat University who were already enrolled to study at various engineering departments, and thus were receiving compulsory English prep-class education during the academic year of 2012-2013. As one of the researchers was teaching these students at the time, the method of convenience sampling, in which members of the target population are selected for the purpose of the study if they meet certain practical criteria, such as geographical proximity, availability at a certain time, or easy accessibility (Dörnyei, 2010), was used. The sample consisted 271 students who voluntarily wanted to take part and answer the questionnaires administered by the researchers. These students were subjected, by the school of Foreign Languages at Firat University, to take a foreign language achievement test before they could start receiving education in the departments they had already gained right to study. Those having failed in this exam went on to attend a one-year prep-class education. The students took a summative achievement test at the end of the prep-education. The academic achievement criteria were 70 for both exams. Those graded with 70 and over from these exams were exempt from the foreign language prep-class education. In order to collect data, the Foreign Language Classroom Anxiety Scale developed by Horwitz, Horwitz and Cope (1986) was used. The latest validity-reliability of this scale was conducted by Gürsu (2011), in which the three-factor structure of the original scale was confirmed. These factors were relabeled by Gürsu (2011) as speaking anxiety in language class, interest towards language class and anxiety of talking with native speaker. The test-retest correlation of the scale was found as .85 . The data of this study were limited to the foreign language anxiety scale and the achievement test scores of the students. The data of the study were analyzed with the standard (enter) method of the logistic regression analysis. Logistic regression is used to measure the relationship between categorical dependent variable and one or more independent variables, which are generally continuous, by predicting probabilities. In other words, logistic regression is an appropriate kind of analysis when the dependent variable is not continuous (in this case, the achievement scores of the students categorized as successful and unsuccessful). Furthermore, the logistic regression analysis has an important place in categorical data analysis with its regression type logic, and being advantageous because of being more useful compared to other analyses (Çokluk, Şekercioğlu and Büyüköztürk, 2010).

\section{Results}

The first question of the study was whether foreign language anxiety had any impact on the students' achievement scores of the formative achievement test (the scores students got from the foreign language achievement test done before the prep-class education).When a logistic regression analysis was conducted for this question, it was observed that the -2LL (-2log probability) value started with 231.209. When it is considered that the -2LL value for perfect fit is zero (0) (Çokluk, Şekercioğlu and Büyüköztürk, 2010), the value above-mentioned is considerably high. Upon the evaluation of the case in terms of the predictive variables in the analysis, the results of the first categorization were found to be as in Table 1 . 
Table 1. The first categorization table of the predictive variables

\begin{tabular}{|c|c|c|c|c|}
\hline \multirow[t]{2}{*}{ Unobserved true / Observed } & \multirow[t]{2}{*}{ case } & \multicolumn{2}{|c|}{ Estimated Case } & \multirow[t]{2}{*}{ Correct categorization percentage } \\
\hline & & Unsuccessful & Successful & \\
\hline Unsuccessful & & 231 & 0 & 100.0 \\
\hline \multirow[t]{2}{*}{ Successful } & & 40 & 0 & 0 \\
\hline & Tot & rrect categoriz & percentage & 85.2 \\
\hline
\end{tabular}

On analyzing Table 1, it is understood that all the students in the prep-class were categorized within the unsuccessful group, and the correct categorization percentage was $85.2 \%$. And the Wald statistic results of the variables in the first model were as $\beta=-1.754$, Standard Error $=.171$, Wald $=104.841$, value of freedom $=1$, value of significance .000 , $\operatorname{Exp}(\beta)=.173$. The Wald statistic is widely used in order to test the significance of the logistic regression coefficient for each predictive variable. The results of the variables which were not in the first model (predictive variables) are given in Table2.

Table 2. The Results of the predictive variables before foreign language prep-education

\begin{tabular}{lrrrr}
\hline & Sariables & Score & sd & $\mathrm{p}$ \\
\cline { 2 - 5 } Step 0 & Speaking Anxiety & 2.334 & 1 & .127 \\
& Interest towards language class & 6.397 & 1 & .011 \\
& Anxiety of talking with native speaker & .000 & 1 & .991 \\
Error Chi-square statistics $\left(\mathrm{x}_{\beta 0}^{2}\right)$ & 7.534 & 4 & .110 \\
\hline
\end{tabular}

It is seen that the error chi-square value in Table 2 is not statistically significant $\left(X_{\beta o}^{2}=7.534, \mathrm{p}>.05\right)$. Although no significant difference was observed, it was found that the interest towards language class factor was at a significant level. However in such cases, it is generally interpreted, by looking at the error chi-square value, that the predictive variables that have not been included in the model do not make any significant contribution to the predictive power of the model, and the analysis is thus finalized (Çokluk, Şekercioğlu and Büyüköztürk, 2010).

The second question of the study was whether foreign language anxiety had any impact on the students' achievement scores of the summative achievement test (the scores the students got from the foreign language achievement test done after the prep-class education). When a logistic regression analysis was conducted for this question, it was observed that the -2LL (-2log probability) value started with 330.711. Upon the evaluation of the case in terms of the predictive variables in the analysis, the results of the first categorization were found to be as in Table 3 .

Table 3. The Categorization of the predictive variables after foreign language prep-education

\begin{tabular}{rccc}
\hline Unobserved true / Observed case & \multicolumn{2}{c}{ Estimated Case } & Correct Categorization Percentage \\
\cline { 2 - 3 } & Unsuccessful & Successful & \\
\hline Unsuccessful & 190 & 0 & 100.0 \\
Successful & 81 & 0 & 0 \\
Total correct categorization percentage & 70.1 \\
\hline
\end{tabular}

It was identified that all the students in the prep-class were categorized within the unsuccessful group, and the correct categorization percentage fell down to $70.1 \%$. And the Wald statistics results of the variables in the first model were as $\beta=-.853$, Standard Error $=.133$, Wald $=41.279$, value of freedom $=1$, value of significance .000 , $\operatorname{Exp}(\beta)=.426$. The results of the variables which were not in the first model (predictive variables) are given in Table4.

Table 4. The Results of the predictive variables after foreign language prep-education

\begin{tabular}{rlrrr} 
& Variables & score & sd & $\mathrm{p}$ \\
\cline { 2 - 6 } Step 0 & Speaking Anxiety & 3.977 & 1 & .046 \\
& Interest towards language class & 18.342 & 1 & .003 \\
& Anxiety of talking with native speaker & 3.756 & 1 & .053 \\
& Error Chi-square statistics $\left(\mathrm{x}^{2}{ }_{\text {Bo }}\right)$ & 26.680 & 4 & .000 \\
\hline
\end{tabular}

The error chi-square value in Table 4 is statistically significant $\left(X_{\beta o}^{2}=26.680, \mathrm{p}<.05\right)$. The significance of this value shows that the coefficients of the predictive variables that were not included in the model are significantly different from zero. It can be suggested that the inclusion of one or more of these variables into the model will increase the predictive power of the model. The calculated Hosmer \& Lemeshow value was as Chi-square $=6.396, \mathrm{sd}=8$ and $\mathrm{p}=.603$. The significance of the Hosmer \& Lemeshow value shows that the model does not have the acceptable fit (Çokluk, Şekercioğlu and Büyüköztürk, 2010:93). Thus, as the value found is not significant in this regard, the goodness of fit of the model is at an adequate level. The categorization table of the model obtained as a result of the Logistic regression was found to be as in Table5. 
Table 5. The categorization table of the model obtained as a result of the Logistic regression

\begin{tabular}{rrrrr}
\hline \multirow{2}{*}{$\begin{array}{c}\text { Unobserved true / Observed } \\
\text { case }\end{array}$} & \multicolumn{2}{c}{ Estimated Case } & Correct Categorization \\
\cline { 3 - 5 } & Unsuccessful & 180 & Successful & 94.7 \\
& Successful & 66 & 10 & 18.5 \\
& & Total correct categorization percentage & 72.0 \\
\hline
\end{tabular}

On analyzing the first categorization results, the correct categorization ratio for the unsuccessful was $70.1 \%$, while the correct categorization ratio increased to $72.0 \%$ as a result of the logistic regression analysis model. And out of 190 unsuccessful students, 180 of them were categorized correctly, while 10 of them were categorized incorrectly; and out of 81 successful students, 15 of them were categorized correctly whereas 66 of them were categorized incorrectly. The coefficient estimates of the targeted model variables were found to be as in Table 6 .

Table 6 . The coefficient estimates of the target model variables

\begin{tabular}{llrrrrrr}
\hline Step & $\beta$ & S. Error & Wald & df & $p$ & $\operatorname{Exp}(\beta)$ \\
\hline 1 & Speaking Anxiety & -2.228 & 1.102 & 4.085 & 1 & .043 & .108 \\
& Interest towards language class & .582 & .259 & 5.043 & 1 & .025 & 1.790 \\
& Anxiety of talking with native speakers & .167 & .247 & .459 & 1 & .498 & 1.182 \\
& Standardized & -5.294 & 1.160 & 20.843 & 1 & .000 & .005 \\
\hline
\end{tabular}

According to the results in Table6, the foreign language prep-education speaking anxiety of the students is affected by the interest towards language class and the foreign language classroom anxiety in general, but not affected by the anxiety of talking with native speakers. The categorization equation in accordance with this can be stated as: $=-5.294-$ $2.228 x$ (Speaking anxiety) $+.582 x$ (interest towards language class). In other words, one (1) unit increase in the predictive variable 'Speaking Anxiety' leads to an increase with the rate of $89.2 \%$ in the unsuccessful odds [(1-0.108)x100], and one unit increase in the predictive variable 'interest towards language class' leads to an increase of $79 \%$ in academic achievement.

\section{Discussion}

The term foreign language anxiety has mostly been used to define tension and appraisal feelings especially associated with second language learning contexts (Dewaele, 2007). It is claimed that foreign language anxiety is, among affective factors, the most powerful predictor of learners' foreign language performance (Liu \& Huang, 2011; as cited in Al-Shboul et al., 2013). In this regard, this study aimed to investigate to what extent the foreign language anxiety the students having received compulsory prep-class education experienced could affect their academic achievement before and after their education. According to the findings, the foreign language anxiety at the beginning of the prep-class education was not effective as the predictor of the academic achievement. On the other hand, it was observed that the students' anxiety, at the end of the education, accounted for the academic failure with its speaking anxiety in language class dimension, and predicted academic achievement with its interest towards language class dimension. It was reported in the literature that a strong speaking anxiety factor is a typical component of the foreign language classroom anxiety (Cheng et al., 1999). In parallel with the results of the study, Huang (2012) cites that anxiety impedes the language learning process. The finding that anxiety cannot be one of the predictors of the students' achievement at the beginning of their prep-education can be explained with MacIntyre and Gardner (1989)'s claim that students do not start language learning with anxiety, but anxiety is a learned emotional reaction, and it appears after students' attitudes towards language learning develop. Aydemir (2011)'s study, in which a significant increase emerged in the students' foreign language anxiety levels at the end of their prep-class education, also shows that students' anxiety evolves and increases throughout the teaching process. Moreover, the suggestion that poor performance and negative emotional reactions may increase anxiety and failure expectations (MacIntyre \& Gardner, 1991; Horwitz, 2001) is also compatible with this study. On the other hand, the development of three components of the foreign language classroom anxiety construct (fear of communication, fear of negative evaluation and test anxiety), proposed by Horwitz, Horwitz \& Cope (1986), in students during their prep-education may also have caused their poor performance. Foreign language classroom anxiety may be caused by many such individual and external factors as learners' and teachers' beliefs about language learning, teacher-learner interactions, exams, in-class procedures, etc. (Young, 1991), and may affect foreign language learning in many respects. This study revealed that the students' anxiety evolving and ever-increasing during their English prep-education powerfully predicted their academic performance. Whatever its source may be, anxiety in learning environments is mostly an unwanted situation. Therefore, it has always been underlined in the literature that in order to facilitate learners' language learning process, the effect of anxiety should be minimized (Huang, 2012). 


\section{References}

Aida, Y. (1994). Examination of Horwitz, Horwitz, and Cope's construct of foreign language anxiety: The case of students of Japanese. Modern Language Journal, http://dx.doi.org/10.1111/j.1540-4781.1994.tb02026.x

Al-Shboul, M. M., Ahmad, I. S., Nordin, M. S., \& Rahman, Z. A. (2013). Foreign Language Anxiety and Achievement: Systematic Review. International Journal of English Linguistics, 3(2), 32-45. http://dx.doi.org/10.5539/ijel.v3n2p32

Awan, R., Azher, M., Anwar, M., N., \& Naz, A. (2010). An investigation of foreign language classroom anxiety and its relationship with students' achievement. Journal of College Teaching and Learning, 7(11), 33-40.

Aydemir, O. (2011). A Study on the Changes in the Foreign Language Anxiety Levels Experienced by the Students of the Preparatory School at Gazi University during an Academic Year. Unpublished Master's Thesis. Gazi University Institute of Educational Sciences, Ankara.

Batumlu-Uslu, Zeynep, D. (2006). YTÜ Yabancı Diller Yüksek Okulu Hazırlık Öğrencilerinin Yabancı Dil Kaygılarının Ingilizce Başarllarına Etkisi. Unpublished MA Thesis. Yıldız Teknik Üniversitesi, İstanbul.

Campbell, C. M., \& Ortiz, J. (1991). Helping students overcome foreign language anxiety: A foreign language anxiety workshop. In E.K. Horwitz \& D.J. Young (Eds.), Language anxiety: From theory and research to classroom implications. (pp. 141- 150). Englewood Cliffs, New Jersey: Prentice Hall.

Cheng, Y.S., Horwitz, E.K., \& Schallert, D.L. (1999). Language anxiety: Differentiating writing and speaking components. Language Learning, 49(3), 417-446. http://dx.doi.org/10.1111/0023-8333.00095

Çokluk, Ö., Şekercioğlu, G., \& Büyüköztürk Ş. (2010). Multivariate statistics for the social sciences: SPSS and LISREL Applied. Ankara: PegemA Publishing

Demirdaş, Ö., \& Bozdoğan, D. (2013). Foreign language anxiety and performance of language learners in preparatory classes. Turkish Journal of Education, 2(3), 4-13.

Dewaele, J. M. (2007). The effect of multilingualism, socio-biographical, and situational factors on communicative anxiety and foreign language anxiety of mature language learners. International Journal of Bilingualism, 11(4), 391-409. http://dx.doi.org/10.1177/13670069070110040301

Dörnyei, Z. (2010). Questionnaires in Second Language Research: Construction, Administration, and Processing. Routledge: NY.

Elkhafaifi, H. (2005). Listening comprehension and anxiety in the Arabic language classroom. The Modern Language Journal, 89(2), 206-220. http://dx.doi.org/10.1111/j.1540-4781.2005.00275.x

Ganschow, L., Sparks, R. L., Anderson, R., Javorsky, J., Skinner, S., \& Patton. J. (1994). Differences in language performance among high-, average-, and low anxious college foreign language learners. The Modern Language Journal, 78(1), pp. 41-55. http://dx.doi.org/10.1111/j.1540-4781.1994.tb02013.x

Goetz, T., \& Hall, N. (2013). Emotion and Achievement in the Classroom. In J. Hattie\& E.M. Anderman (Eds), International Guide to Student Achievement (pp. 192-195). New York: Routledge.

Gürsu, F. (2011). The Turkish Equivalence, Validity, and Reliability Study of the Foreign Language Classroom Anxiety Scale, Unpublished Master's Thesis. Yeditepe University, Institute of Social Sciences İstanbul.

Hao, M., Liu, M., \& Hao, R. (2004). An empirical study on anxiety and motivation in English as a foreign language. Asian Journal of English Language Teaching, 14, 89-104.

Hewitt, E., \& Stephenson, J. (2011). Foreign language anxiety and oral exam performance: A replication of Phillips's MLJ study. The Modern Language Journal, 96, 170-189. http://dx.doi.org/10.1111/j.1540-4781.2011.01174.x

Horwitz, E. K. (2001). Language anxiety and achievement. Annual Review of Applied Linguistics, 21, $112-126$. http://dx.doi.org/10.1017/S0267190501000071

Horwitz, E. K., Horwitz, M. B., \& Cope, J. A. (1986). Foreign language classroom anxiety. The Modern Language Journal, 70, 125-132. http://dx.doi.org/10.1111/j.1540-4781.1986.tb05256.x

Huang, J. (2012). Overcoming Foreign Language Classroom Anxiety. Nova Science Publishers, Inc.: New York.

Huberty, T. J. (2009). Test and performance anxiety. Principal Leadership, 10, 12-16. 
Kılıç, M. (2007). The Sources And Relations Of Foreign Language Listening Anxiety With Respect To Text Type And Learner Variables: A Case Study At Gaziantep University, Unpublished Master's Thesis. Gaziantep University, Institute of Social Sciences.

Kunt, N. (1997). Anxiety and beliefs about language learning: A study of Turkish-speaking university students learning English in North Cyprus. Applied Psycholinguistics, 20, 217-239.

MacIntyre, P. D. (1995). On seeing the fore stand the trees: A rejoinder to Sparks and Ganschow. The Modern Language Journal, 79(2), 245-248. http://dx.doi.org/10.1111/j.1540-4781.1995.tb05438.x

MacIntyre, P. D., \& Gardner, R. C. (1991). Methods and results in the study of anxiety and language learning: A Review of the Literature. Language Learning, $41 \quad$ (1), 85-117. http://dx.doi.org/10.1111/j.1467-1770.1991.tb00677.x

MacIntyre, P., \& Gregersen, T. (2012). Affect: The Role of Language Anxiety and Other Emotions in Language Learning. Mercer, S.,Ryan, S. \& Williams, M. (Eds.). Psychology for Language Learning. Palgrave Macmillan, 103-116. http://dx.doi.org/10.1057/9781137032829.0012

Onwuegbuzie, A., Philip, B., Christine, E. D. (1999). Factors associated with foreign language anxiety. Applied Socio Linguistics, 20, 218-239. http://dx.doi.org/10.1017/s0142716499002039

Oxford, R., (1999). Anxiety and The Language Learner: New Insights. In Jane, A. (Ed.), Affect In Language Learning. Cambridge University Press, 58-67.

Phillips, E. M. (1992). The effects of language anxiety on students' oral test performance and attitudes. The Modern Language Journal, 76(1), 14-26. http://dx.doi.org/10.1111/j.1540-4781.1992.tb02573.x

Proulx, P. (1991). Anxiety in language learning: Recognition and prevention. Canadian Journal of Native Education, $18,53-64$.

Riasati, M. J. (2011). Language Learning Anxiety from EFL Learners' Perspective. Middle East Journal of Scientific Research, 7(6), 907-914.

Saito, Y, Horwitz, E. K., \& Garza, T. J. (1999). Foreign language reading anxiety. Modern Language Journal, 83, 202-218. http://dx.doi.org/10.1111/0026-7902.00016

Wang, J.R. (2011). Foreign Language Classroom Anxiety and English Academic Performance Among Medical University Students in Taiwan, Unpublished PhD Dissertation. La Sierra University, TheFaculty of School of Education.

Young, D. J. (1991). Creating a low-anxiety classroom environment: what does language anxiety research suggest? The Modern Language Journal, 75(4), 426-439. http://dx.doi.org/10.1111/j.1540-4781.1991.tb05378.x

Young, D. J. (1999). Affect in Foreign Language and Second Language Learning: A practical guide to creating a low-anxiety classroom atmosphere. McGraw-Hill Companies: the USA

\section{$(\mathrm{Cc}) \mathrm{BY}$}

This work is licensed under a Creative Commons Attribution 3.0 License. 